\title{
The changing chagras: traditional ecological knowledge transformations in the Colombian Amazon
}

\author{
$\underline{\text { Valentina Fonseca-Cepeda }}^{1}, \underline{\text { C. Julián Idrobo }}^{2}$ and Sebastián Restrepo $^{3}$
}

\begin{abstract}
Shifting agriculture systems in the Colombian Amazon, locally known as chagras, have been traditionally managed by indigenous peoples following their traditional ecological knowledge (TEK). However, different socioeconomic drivers of change are affecting indigenous chagra TEK, resulting in changes in practices and land-use patterns. This study examines TEK transformations from 1970 to 2016 and their relation to rainforest management in the Ticuna indigenous resguardo of El Vergel (Leticia Municipality, Amazonas Department). It employs an ethnographic case study design that articulates quantitative data on land-use variables related to chagras and qualitative ethnographic data describing dimensions of TEK and its perceived transformations, including knowledge of the environment, practices and management systems, social institutions, and worldviews. Our findings reveal that TEK transformations entail changes in land-use, including size of production area, temporality of land-use, and cultivated diversity. This study contributes to a reinterpretation of TEK transformations and emphasizes the importance of the chagra as an adaptive system. The TEK transformations related to chagras imply a constant reattunement of relations that bind people and their environments. Rather than being frozen in an ethnographic past, people have responded to social and economic drivers to meet their current needs and aspirations. Likewise, understanding TEK transformations and their relation to changes in land-use practices provides relevant insights about social-ecological dynamics in the Amazon rainforest to navigate change and provide the basis for a discussion of how to enrich management decisions to move toward sustainability in tropical forests.
\end{abstract}

Key Words: Amazon rainforest; chagra; Colombia; indigenous people; land use; traditional ecological knowledge

\section{INTRODUCTION}

Globalization processes have affected the Amazon region over many centuries, dramatically changing its ecology and the ways of life of its inhabitants (Laurance et al. 2011, Gómez 2015). The Ticuna indigenous people have inhabited this region for centuries and have experienced, responded, and adapted to profound changes brought about by colonialism and associated agroindustrial development, deforestation, loss of autonomy, and violence (Franco 1992, Ullán 2000). The chagra, a shifting agriculture system, has been practiced since pre-Columbian times by the Ticuna. However, this system has not remained static. Ticuna management systems and associated traditional ecological knowledge (TEK) have transformed in response to the changing socioeconomic contexts in which their ways of life are embedded. These transformations express actors' capacity to define and create new configurations of knowledge and practice, responding to driving forces (Walker et al. 2004). Socioeconomic (SE) drivers of change are rooted in economic dynamics and are strongly related to government programs, laws, and policies (Bürgi et al. 2004).

We examined processes of TEK transformation and production in the context of a Ticuna indigenous community's relationships with the chagra in the Colombian Amazon. Understanding how TEK changes in relation to local manifestations of globalization and other SE drivers of change provides insights about the adaptation of social-ecological systems. By employing Berkes et al.'s (2000) knowledge-practice-belief framework, we traced the drivers of change underlying TEK transformations and their effects in human-environment relations in El Vergel. Berkes et al. (2000:1252) defined TEK as "a cumulative body of knowledge, practice, and belief, evolving by adaptive processes and handed down through generations by cultural transmission, about the relationships of living beings (including humans) with one another and with their environment." Starting with the premise that TEK is dynamic and provides tools to navigate change, we analyzed the factors that underlie changes in land-use patterns in the Amazon. In doing so, we contribute to the discussion in this Special Issue and elsewhere surrounding how indigenous and local people manage change and the quest for sustainable pathways for transformation in the Amazon region.

In the last sixty years, we have experienced ecological transformations of unprecedented scale, rate, and intensity around the globe (Ellis 2015). Land-use changes have altered the structure and functioning of ecosystems, including their ability to provide key services for human well-being (MEA 2003, Ramankutty et al. 2008, Lambin and Meyfroidt 2010). In the tropics, the expansion of the capitalist agricultural frontier, road development, and timber extraction have led to widespread deforestation, and habitat and biodiversity loss (Lambin et al. 2001, Foley et al. 2005). During the 1990s, natural forests decreased by 16.1 million hectares per year at the global level and by 15.2 million hectares in tropical regions (Lambin et al. 2003). In turn, these changes are associated with the loss of natural resource-based livelihoods, affecting local peoples' social and cultural capital (van Vliet et al. 2012, 2013), in which indigenous peoples have been particularly affected because of their close relationship with their local environment.

Shifting agriculture remains the most common productive practice in the Amazon region utilized by most of the rural population (Coomes et al. 2000, Padoch and Pinedo-Vásquez 2010, Junqueira et al. 2016). Nevertheless, integration to markets, implementation of biodiversity conservation strategies, mechanization of agriculture, access to formal education,

${ }^{1}$ Pontificia Universidad Javeriana, Bogotá, Colombia, ${ }^{2}$ Centro Interdisciplinario de Estudios sobre Desarrollo, Universidad de los Andes, Bogotá, Colombia, ${ }^{3}$ Departamento de Desarrollo Rural y Regional, Pontificia Universidad Javeriana, Bogotá, Colombia 
government policies geared toward hunger eradication, and local aspirations associated with urban lifestyles have had major effects on this productive system (Fox et al. 2009, Adams et al. 2013, Schmook et al. 2013, Junqueira et al. 2016, Coomes et al. 2017). These drivers have resulted in the reduction of cultivated areas and in cultivated diversity, more intensive productive systems, increase in rural-urban migration, and livelihood diversification toward non-natural resource-based activities (Cramb et al. 2009, Schmidt-Vogt et al. 2009, van Vliet et al. 2012). Although shifting agriculture systems have historically been recognized as dynamic and diverse (Padoch et al. 2007), current development pathways suggest a need to craft future trajectories in which sustainability of local communities and environments are a priority. Moreover, there is an urgent need to understand how social-ecological transitions related to the adaptive capacity of indigenous peoples could be enhanced through the encouragement of innovation, learning, and empowerment to manage change (Westley et al. 2011).

The chagras from the Colombian Amazon are valuable hubs of practice in which indigenous peoples apply and produce knowledge related to the ecological dynamics of tropical rainforests. Different studies have shown the vast body of ecological knowledge that underlies these systems, in particular knowledge related to the careful selection of plots and the accurate recognition of light intensity, soil nutrients, and diverse vegetation strata (Vélez and Vélez 1999, Rodríguez 2013, Peña 2015, Mendoza et al. 2017). The management of multiple components of the environment over time and space in chagras makes up a cyclical process of intervention in the rainforest that assures continuous and sustainable production of food (Correa 1990), which consists of place selection, land clearing, logging, burning, sowing, tending, harvesting, second sowing, fallow period, abandonment, and ultimately return of the site to the spiritual owners of the land (Andrade 1990, Kleinman et al. 1995, Bríñez Pérez 2002, Triana et al. 2006, Andoque and Castro 2012, Rodríguez and Van der Hammen 2014; Fig. 1). Through this process, indigenous peoples plan and enact sustainable livelihood strategies focused on maintaining and regenerating the rainforest and its soils.

Fig. 1. Land clearing, seed selection, tending, and harvesting.

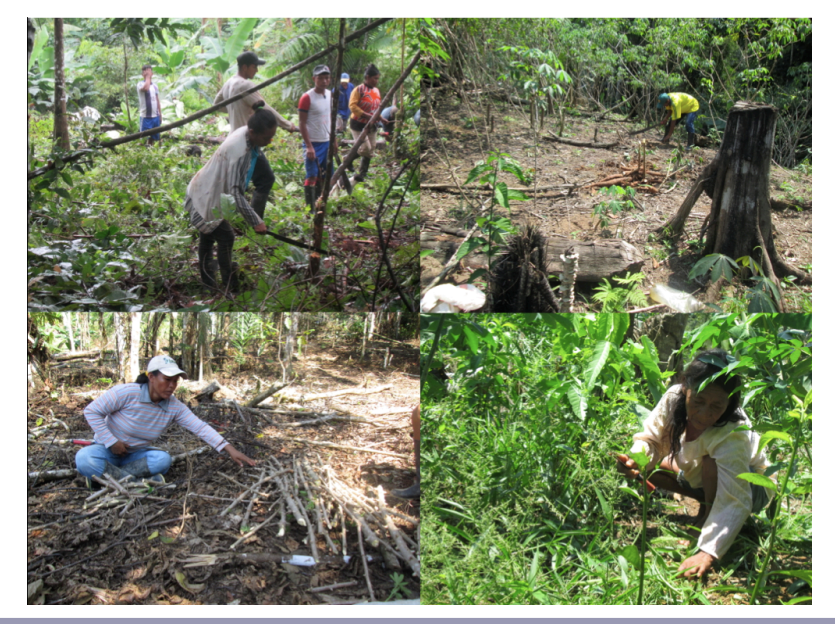

In addition to the knowledge associated with biodiversity and ecological cycles, chagras also have symbolic dimensions entwined with the epistemologies and ontologies of Ticuna and other indigenous peoples (Hugh-Jones 1979, Rodríguez and Van der Hammen 1990, Van der Hammen 1992). As a physical space, chagras support the material and spiritual existence of indigenous communities (Bríñez 2002). Accordingly, they reproduce physical and intangible elements of their cosmology in a geographically and temporally defined space through interactions within the social-ecological system (Carrizosa 2016). In this study, chagras are understood as social-ecological units that have faced historical transformations mediated by the knowledge of Amazon indigenous peoples.

This study deals with TEK from a constructivist perspective that sees knowledge as a process rooted in history, practice, social relations, place, and identity. Among the themes that this research stream focuses on is the historical relationship between globalization, land-use and environmental policies, and integration to markets as SE drivers of change (Bürgi et al. 2004) that lead to changes in social actors' practices (Hersperger et al. 2010) through the transformation of knowledge (Heckler 2009), shaping specific land-use arrangements. Thus, historical events are expressions of driving forces that affect TEK related to landuse systems. These transformations may include changes in the temporality of land use, size of production area, and cultivated diversity reflecting actors' decision making in response to multiscale dynamics of change (Morzillo et al. 2015).

From an analytical standpoint, we employed Berkes et al.'s (2000) TEK framework because their use of traditional and ecology concepts aligns with our analysis of the transformations that the chagra and the knowledge associated with it have undergone during the timeframe of this study.

Within this framing, TEK is a body of knowledge composed of four levels that articulate a knowledge-practice-belief complex that sustains forest management. First, there is the local knowledge of biodiversity, soils, and landscape. In the context of the chagra, this level includes knowledge of ecological and biophysical features' taxonomy, life cycles of plants and animals, and nutritional and medicinal properties of cultivated diversity. At the second level, there is a resource management system that includes a set of productive practices and techniques that require an understanding of ecological processes, such as forest succession patterns, flood pulses, and moon phases. The third level includes sets of social institutions and rules-in-use that determine gender roles, taboos, and otherwise regulate resources use and access. Finally, the fourth level encompasses worldview and environmental perception, as well as the multiple ways in which human's position themselves in relation to the environment and other beings. For the Ticuna, the chagra represents the management of the territory, the relations between spiritual and material dimensions, and the place where the memories of their ancestors are expressed.

In keeping with other work in the area of processual ethnobiology (Heckler 2009, Idrobo and Davidson-Hunt 2012), Berkes et al. (2000) deal with TEK as an adaptive process. Instead of referring to knowledge from the past, "traditional" in this sense refers to the processes that connect past and future. Likewise, "ecology" refers to the relations that individuals forge with their 
Fig. 2. Ticuna chagras studied in the Indigenous Resguardo of El Vergel (Amazonas, Colombia).

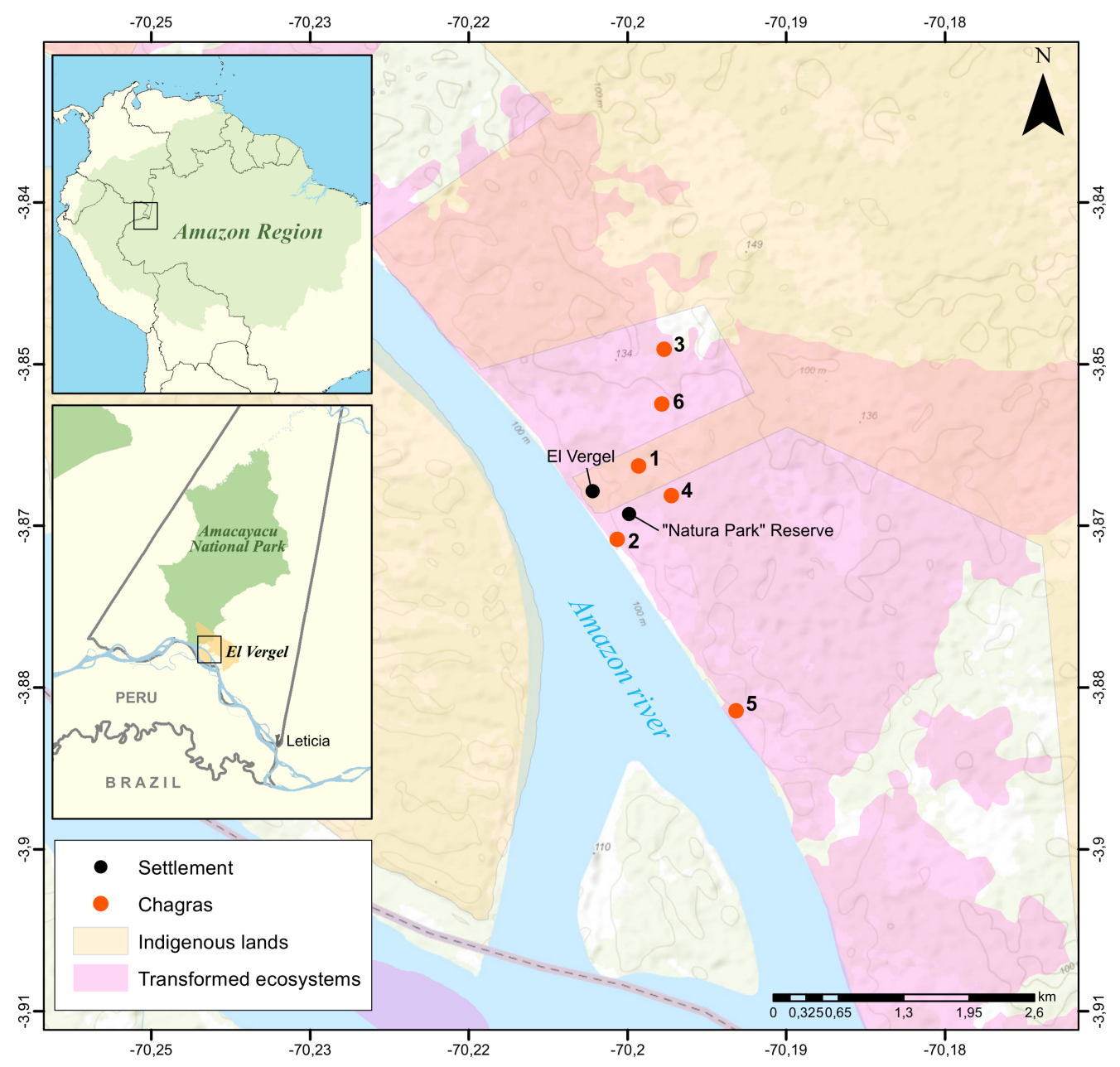

environments as they move through them on their life paths (Ingold 2000, Davidson-Hunt 2006). Understanding knowledge as a dynamic process provides a platform for critically understanding how human-environment relations change over time. Traditional ecological knowledge and its transformations are not bounded by immediate social-ecological contexts, but rather are a necessary outcome of the interactions between situated knowledge and regional and global processes (Ellen 2007, Alexiades 2009).

Within the global context of widespread loss of indigenous languages, ongoing struggles for territory, and acculturation linked with colonialism, TEK transformations among indigenous and local peoples have generated concern worldwide and have prompted research to understand and address them (Maffi 2001). The main transformation that has been measured is the intergenerational loss of knowledge about plants and animals as well as the necessary skills for subsistence lifestyles (Godoy et al. 2005, Gómez-Baggethun et al. 2013). Despite its contributions, this approach to knowledge loss is riddled with contradictions that limit understandings of the effects of social and economic change on TEK and the impacts for indigenous and local peoples. It not only bounds TEK to knowledge of local taxonomies and land-based practices, but also assumes that the TEK of a society or group of people is an immutable body of information (Davidson-Hunt 2006, Nabhan et al. 2011).

\section{METHODS}

\section{Study site}

We conducted this study at El Vergel Ticuna Indigenous Territory (Resguardo El Vergel in Spanish) located on the bank of the Amazon River, $54 \mathrm{~km}$ northwest of Leticia, the capital of the Amazonas Department, Colombia (Fig. 2). El Vergel has an area of 2325 hectares and a population of 396 , grouped in 40 households. With an average temperature of $26^{\circ} \mathrm{C}$ and an average annual precipitation of $3193 \mathrm{~mm}$, El Vergel is a lowland tropical humid forest (Sinchi 2016). In 1970, a few families that migrated from Brazil to the north side of the Amazon River in the Colombia territory, settled at El Vergel. The Vergel Resguardo is currently held under a common property title granted in 1983 as part of a national political process aimed at recognizing indigenous peoples' rights over their ancestral lands (Carrizosa 2016).

Ticuna peoples are one of the most numerous indigenous groups in the Amazon basin and currently occupy a strip of 1000 
Table 1. Summary of research methods.

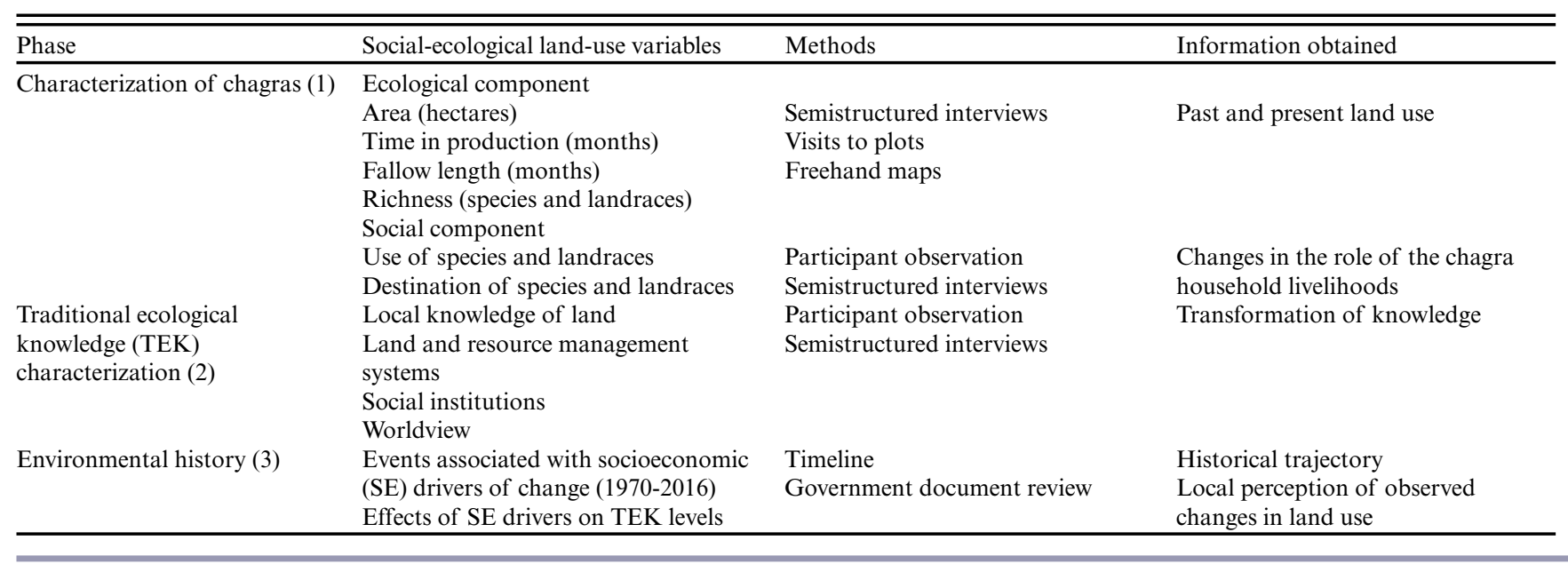

kilometers along the Amazon River between Brazil, Peru, and Colombia. In the last 200 years, Ticuna from El Vergel and the rest of the riverbank have experienced profound changes in their ways of life as a result of the processes of colonization: slavery and evangelization (18th century), the rubber and fur bonanzas (19th century), and illicit crops and tourism (20th century; Oyuela and Vieco 1999). These historical processes forced them, not only to change their settlement patterns from malocas to permanent villages, but also to modify their land-use systems.

\section{Study design}

This research followed an ethnographic case study design that combined quantitative data obtained from a survey of six chagras, qualitative data related to TEK changes in chagra use over time, and key historical events research that participants associated with those changes. After consulting with indigenous authorities and owners of each chagra, Fonseca collected data during August and September 2016 (Table 1). We analyzed TEK transformations related to structural and functional attributes of the chagra at each TEK level in relation to key historical events (Berkes 2012).

In the first phase, we assessed the social and ecological attributes of six chagras belonging to six households. Although families can own more than one chagra at a time, we sampled one chagra per family to include more households in our study. We gathered data on variables related to land use, such as cultivation area, time of production, fallow length, and cultivated diversity. To see changes in the role of the chagra in household livelihoods, we considered the uses and destinations of cultivated species and landraces. Direct observations and semistructured in-depth interviews with household members (male and female household heads, for a total of 12 interviewees) provided the bulk of the data. We collected corresponding information during visits to plots and drew freehand maps of each cultivated space (von Hildebrand 1975). Based on the preliminary data, we asked interviewees about changes in land use during their living memory. In this way, we established differences in the size of the households' cultivation areas and the changes in composition of the chagras between 1970 and 2016.
The second phase focused on TEK associated with chagras, including local knowledge of ecosystems, land and resource management systems, social institutions, and worldviews (Berkes 2012). Participant observation on daily journeys with research participants to their chagras was a fundamental tool for the collection of qualitative data (Kawulich 2005). Semistructured interviews with elders addressing each level of TEK were used to triangulate and enrich data gathered through participant observation.

In the third phase, we compiled local perceptions of recent change related to chagras and complemented local narratives through a review of national archives and reports from local villagers (Gallini et al. 2015). Then, we verified this information in a timeline workshop (Candelo et al. 2003), in which a focus group of six people identified critical moments in the history of the community associated with SE drivers of change between 1970 and 2016. Finally, we assessed the implications of those moments on land-use change, considering the social-ecological land-use variables shown in Table 1.

\section{RESULTS}

We found that many TEK transformations took place between 1970 and 2016 in response to multiple SE drivers. These transformations brought about visible changes in land-use patterns and represent social-ecological processes related to the persistence of chagras as a significant component of local livelihoods. Table 2 summarizes key events that transformed the TEK associated with chagras at different levels.

As many indigenous settlements in Amazon region, El Vergel tells a dynamic history of indigenous movements and migrations. From the 18th century until the 1970s, slavery, evangelization, rubber and fur bonanzas, and illicit crops forced members of the Ticuna people to be relocated to the area that would later become El Vergel Resguardo. At the time, however, a colonist privately owned the area. Those who arrived had employed shifting agriculture systems during their migration process from Brazil and opened new chagras as soon as they arrived at El Vergel. The newly arrived Ticuna were required to provide labor on the 
Table 2. Socioeconomic (SE) drivers of change and traditional ecological knowledge (TEK) transformations in El Vergel Resguardo.

\begin{tabular}{|c|c|c|c|c|c|}
\hline \multirow{2}{*}{$\begin{array}{l}\text { Time } \\
\text { period }\end{array}$} & \multirow[t]{2}{*}{ Key event(s) } & \multicolumn{4}{|c|}{ Levels of traditional ecological knowledge } \\
\hline & & $\begin{array}{l}\text { Local Knowledge of } \\
\text { Land }\end{array}$ & $\begin{array}{l}\text { Land and Resource } \\
\text { Management Systems }\end{array}$ & Social Institutions & Worldview \\
\hline 1970 & $\begin{array}{l}\text { Conflict for land tenure } \\
\text { between the landowner } \\
\text { and Ticuna people. } \\
\text { Landholder farm hires } \\
\text { Ticuna as wage labor. }\end{array}$ & & $\begin{array}{l}\text { Working in the landholder } \\
\text { farm means less time spent } \\
\text { tending the chagras and less } \\
\text { space allocated for chagra } \\
\text { activities. }\end{array}$ & & \\
\hline 1983 & $\begin{array}{l}\text { Declaration of } \\
\text { indigenous resguardo "El } \\
\text { Vergel" (Resolution 060) } \\
\text { provides legal recognition } \\
\text { of land rights to Ticuna } \\
\text { people. }\end{array}$ & & $\begin{array}{l}\text { Spatial patterns of land use } \\
\text { depend on the political } \\
\text { limits of the resguardo. }\end{array}$ & & \\
\hline 2000 & $\begin{array}{l}\text { Increase in tourism and } \\
\text { associated economic } \\
\text { activities. }\end{array}$ & & $\begin{array}{l}\text { Farming intensification for } \\
\text { tourist food supply. People } \\
\text { stop burning to accelerate } \\
\text { the chagra succession cycles. }\end{array}$ & $\begin{array}{l}\text { Integration with regional } \\
\text { markets: chagra products } \\
\text { are sold to tourists, and } \\
\text { individuals buy groceries in } \\
\text { stores. }\end{array}$ & $\begin{array}{l}\text { People consider } \\
\text { migration to urban } \\
\text { centers. }\end{array}$ \\
\hline 2002 & $\begin{array}{l}\text { Benefits from national } \\
\text { economic development } \\
\text { program. } \\
\text { Familias Guardabosque } \\
\text { (Ranger Families), which } \\
\text { provides subsidies to } \\
\text { encourage fruit } \\
\text { cultivation and timber } \\
\text { tree farming. }\end{array}$ & $\begin{array}{l}\text { Fruit and timber species } \\
\text { become more important } \\
\text { than species of ritual and } \\
\text { medicinal use, leading to } \\
\text { a reduction in cultivated } \\
\text { diversity. }\end{array}$ & $\begin{array}{l}\text { Surge in the production of } \\
\text { food species with } \\
\text { commercial value. }\end{array}$ & & \\
\hline \multirow[t]{2}{*}{2005} & $\begin{array}{l}\text { Benefits from national } \\
\text { cash transfer program } \\
\text { Familias en Acción } \\
\text { (Families in Action), } \\
\text { which provides subsidies } \\
\text { to eradicate hunger and } \\
\text { poverty. }\end{array}$ & $\begin{array}{l}\text { Replacement of } \\
\text { traditional foods by } \\
\text { canned food. Cultivated } \\
\text { diversity is reduced. A } \\
\text { significant portion of } \\
\text { locally consumed } \\
\text { foodstuffs are bought at } \\
\text { local stores or provided } \\
\text { by the state. }\end{array}$ & $\begin{array}{l}\text { Less time is spent tending } \\
\text { chagras and crop cultivation } \\
\text { areas are reduced. }\end{array}$ & & $\begin{array}{l}\text { The chagra is seen as a } \\
\text { means of subsistence but } \\
\text { not as an activity that } \\
\text { connects people with the } \\
\text { territory. }\end{array}$ \\
\hline & $\begin{array}{l}\text { The National Vocational } \\
\text { Training Agency (SENA } \\
\text { for its acronym in } \\
\text { Spanish) offers training } \\
\text { in tourism-related skills } \\
\text { and trades. }\end{array}$ & & $\begin{array}{l}\text { Less time is spent tending } \\
\text { chagras and crop cultivation } \\
\text { areas are further reduced. }\end{array}$ & & \\
\hline 2012 & $\begin{array}{l}\text { The inauguration of } \\
\text { tourism reserve Natura } \\
\text { Park. }\end{array}$ & & $\begin{array}{l}\text { Less time spent in chagras } \\
\text { and more time in building } \\
\text { tourism related } \\
\text { infrastructure and } \\
\text { provisioning tourism } \\
\text { services. }\end{array}$ & & $\begin{array}{l}\text { Territory and the chagra } \\
\text { lose importance in } \\
\text { community livelihoods. } \\
\text { People want to live } \\
\text { outside the region. }\end{array}$ \\
\hline 2016 & $\begin{array}{l}\text { El Vergel receives } \\
\text { subsidies for education } \\
\text { Modalidad Familiar. }\end{array}$ & $\begin{array}{l}\text { New generations learn } \\
\text { knowledge different from } \\
\text { that associated with the } \\
\text { productive practices of } \\
\text { the chagra. }\end{array}$ & & $\begin{array}{l}\text { Child and teenage } \\
\text { participation in chagra } \\
\text { related activities is reduced } \\
\text { because of formal education } \\
\text { schedules. }\end{array}$ & \\
\hline
\end{tabular}

landlord's farm in exchange for access to land for their own cultivation. People depended on the landowner's authorization to cut down forest to open their new chagra plots and to allocate time to work on them. To be able to work on the landowner's farm and receive a wage, people reduced the size of their chagras (Table 3) and spent less time on their own agricultural activities.
Increased dependence on this labor strategy defined informal institutions related to land access and available time allocation that affected temporal and spatial patterns of productive practices (TEK level 2), which in turn had direct effects on land-use activities. As one elder explained: 
Table 3. Changes in land-use patterns as described by households.

\begin{tabular}{lcccc}
\hline & \multicolumn{4}{c}{ Land-use variables } \\
\cline { 2 - 5 } & $\begin{array}{c}\text { Chagra area } \\
\text { (hectares) }\end{array}$ & $\begin{array}{c}\text { Time in } \\
\text { production } \\
\text { (months) }\end{array}$ & $\begin{array}{c}\text { Fallow length } \\
\text { (months) }\end{array}$ & $\begin{array}{c}\text { Number of } \\
\text { cultivated } \\
\text { manioc } \\
\text { landraces }\end{array}$ \\
\hline $\begin{array}{l}\text { Before } \\
1970\end{array}$ & $3-5$ & $24-36$ & $24-72$ & 125 \\
$\begin{array}{l}\text { Current } \\
\text { chagras }\end{array}$ & $0.06-0.34$ & $2-15$ & $6-12$ & 11 \\
\hline
\end{tabular}

We could not start new chagras because when we did so the landowner claimed the land. We spoke to the landowner and, until 1973 he gave us access to a piece of land where we could work (Elder, August 30, 2016).

The recognition of indigenous land rights and the declaration of El Vergel as common property in 1983 changed some of the political and economic dynamics of the area, and gave the community sovereignty over the land in which they had settled. This granted them a greater degree of autonomy over new chagras, but limited production to the boundaries of the Resguardo. Autonomy restructured the social norms related to the use and access to cultivated land (TEK level 3 ) and imposed certain limits on the spatial distribution of chagras in the territory (TEK level 2).

The first decade of the 21 st century saw the implementation of cash transfer payments and subsidy programs (i.e., Familias Guardabosque, Familias en Acción, Modalidad Familiar). Besides medicine and education, they introduced a basic basket of imported foodstuffs that weakened the relationship between the chagra and the dietary needs of the community. After these interventions, people spent less time producing their food and the cultivated diversity reduced. Tobacco (Nicotiana sp.), huito (Genipa americana), achiote (Bixa orellana), and some manioc landraces (Manihot esculenta) are not planted anymore (TEK level 1; see Appendix 1). Along with these changes, production lost cultural significance, became less frequent, and the cultivation areas became smaller and their composition became more homogeneous (TEK level 2; Table 3).

Since the beginning of the 21 st century, the growth of the tourism economy and the integration of local economies with regional markets transformed the chagra's purpose and outcomes from subsistence to commercial trade (see Appendix 1). Around that time, the products from the chagra began to be sold to local restaurants for tourists' consumption and to the families or neighboring communities that had already stopped farming to work in tourism-related jobs. The inauguration of the Natura Park Tourist Reserve in 2012 on the property adjacent to the Resguardo meant a direct integration with the tourism economy. This proximity enabled a close working relationship between the reserve and the Resguardo, which provided local employment but also affected time spent tending chagras (TEK level 2). To adjust to the reduced time available for agricultural activities, people began to accelerate the productive cycle of crops by omitting the burning phase and reducing fallow length, allowing faster harvests and so reducing the chagra's production time (Table 3).
The chagra had a drastic reduction in available labor from other fronts as well, including formal education programs geared toward younger Resguardo members and out-migration to urban centers, such as Leticia. Access to formal education introduced young people to other knowledge systems and at the same time, they reduced their participation in the chagras and they became less familiar with the knowledge associated with agricultural production (TEK levels 1, 2, and 3; Table 2). However, this did not provoke the total replacement of the new generations' participation in productive activities, as affirmed by a farmer:

\section{Sometimes my children can't come with me to the chagra because of their homework, but on the weekends they come help me (Farmer, August 12, 2016).}

Besides the fact that these events led Ticuna in El Vergel to reconfigure their use of cultivated diversity, productive practices, and social institutions associated with the chagra (TEK levels 1, 2, and 3), they also had effects on the way that people positioned themselves in the territory (TEK level4). Integration with regional markets changed the way in which people defined their livelihoods at the local level, for instance, envisioning work outside their territory, providing tourism services, and conceiving chagras as a monetized productive space. Thus, the chagra has transitioned from a reason for living to a means of subsistence. As a farmer reflected:
Our ancestors used to dedicate themselves fully to the chagra before. We now make chagra only for consumption, because other labors no longer give time to tend crops (Farmer, August 29, 2016).

Labor-mediated interactions with the landowner, government cash transfers and subsidy programs, formal education, and tourism are SE drivers of change that have had direct effects on Ticuna's TEK, changing land-use patterns in El Vergel. In response to other time demands and decreased dependence on locally produced crops, farmers changed their chagras through land-use intensification strategies that include crop area reduction, omission of the burning phase before sowing, a decrease of fallow periods, and less time spent tending the chagra (Table 3). These are technical solutions developed by the Ticuna that have allowed them to adapt the chagra to a new regional socioeconomic reality. Although structure, function, and cultural significance of the chagra have changed in El Vergel, people continue to rely on it as the main land-use system in which the Ticuna still find much of their food and income, where there are still spaces for family gatherings, and in which TEK finds opportunities for its creation, recreation, and adaptation.

\section{DISCUSSION}

In El Vergel, SE drivers of change have led to TEK transformations including changes in land-use patterns through increased intensification of the productive dimension of the chagra. In shifting agriculture systems around the globe, we find similar patterns in which local decision-making processes result in reductions of cultivated areas and agrobiodiversity, more intensive productive systems, increases in rural-urban migration, and livelihood diversification toward non-natural resource-based activities (Cramb et al. 2009, Schmidt-Vogt et al. 2009, Van Vliet et al. 2012). 
Such changes might suggest that tropical shifting agriculture systems are bound to disappear, but other studies have found that these systems persist in different contexts and continue to be an important part of local livelihoods, even when they have lost cultural significance (Grogan et al. 2013, Heinimann et al. 2013, Hurni et al. 2013, Schmook et al. 2013, Van Vliet et al. 2013). When indigenous and local people have maintained access to cultivable land, the global pattern has been that these productive systems persist. Thus, despite TEK transformations, the chagra remains an important component of rural livelihoods.

Our analysis, however, not only describes how SE drivers are transforming chagra TEK at multiple levels and the consequences for land-use systems, but also suggests that inside these processes of change lies a key component of how local communities adapt to new realities. Traditional ecological knowledge transformations are important to understand trajectories of change and contribute to crafting sustainable land-use pathways in the Amazon region. Given that chagras are a constantly evolving social-ecological system, to focus solely on the loss of specific units of knowledge obscures and underestimates the processes by which human and environment relations are shaped and reshaped through time and space. The chagra constitutes a setting in which TEK emerges from processes through which Ticuna indigenous communities have learned to live in and from forest ecosystems. Adaptation and transformation define the way in which social-ecological memory is related to ecosystem change (Barthel et al. 2010, Gómez-Baggethun et al. 2013). Chagra transformations are then concrete expressions of this dynamic adaptation process to SE drivers of change.

Despite the integration of local communities to regional markets, there is not always a direct relationship between participation in the market economy and reduction of cultivated diversity. Chagra transformations represent a chain of events in which drivers shape actors' autonomy and motivations, and the actions that result in land-use change (Hersperger et al. 2010). In El Vergel, historical SE drivers changed local livelihoods, affecting everyday decisions people made over their lands. Thus, current market integration has meant a change in chagra composition. Although more species of commercial use are cultivated, fewer species with medicinal or ritual purposes are employed. The composition of the chagra, however, has always changed in response to the nutritional needs of indigenous peoples and the ecological and economic contexts in which they live. Chagra diversity has been known to fluctuate according to the booms and bust of commercial crops and, in other cases, successful market participation has been known to subsidize chagra production (Perrault 2005). Likewise, the fact that some species stop being used at a point in time does not preclude their potential future use (Davidson-Hunt et al. 2016).

In terms of land and resource management systems, our results contribute to understanding the relation between changes in TEK and land-use variables of chagras. Working as wage labor either in commercial agriculture farms or providing services in the tourism sector has meant less time available to work in the chagra. Although this is a recurrent pattern in shifting agriculture systems worldwide and is often linked to people reducing reliance on locally harvested and products resources (Reyes-García et al. 2005, Ellen 2007, Bates et al. 2009), people in El Vergel have not abandoned this productive activity. Instead, they have developed strategies to continue producing in the chagra, while diversifying their livelihoods. These strategies, which imply producing new knowledge about their social-ecological environments, consist of changes in land-use patterns such as reduction in cultivated area, shortening the cultivation cycles by learning to cultivate without burning, and shorter fallow periods. The intensification of chagra could be associated with the minimization of land-use changes in the Amazon rainforest; however, it also could be related to reduced productivity and soil degradation (Kleinman et al. 1994, Mertz 2002, Van Vliet et al. 2012). More research is needed to develop a clearer understanding of the long-term effects of these changes over the productivity of this agricultural system as well as its conservation implications.

In terms of institutions and the productive roles related to shifting agriculture, we found that the new generations move between the chagra and school, playing important roles in both spaces. Rather than knowledge loss, we found that children and young people have been able to integrate academic knowledge as well as agricultural wisdom from their elders in their everyday lives, even as the spaces to participate in the chagra are limited. New generations organize their time and activities to be able to go to school, but continue to learn agricultural knowledge and skills from their parents. The information gained through formal education and the combination of different knowledge systems increase exposure to drivers of change, but also promote the ability of people to adapt to them (Holling 2001). As long as there are spaces to participate in shifting agriculture, children and youth will continue producing new knowledge as they attune their minds and bodies to the changing chagra (Ingold 2000, Lave 2009).

At the worldview level, the chagra has changed its meaning as a way to connect with the territory. Although the symbolic and spiritual connection has lost relevance, the chagra continues to bind people and land together through productive and economic relations. Traditional ecological knowledge transformations registered in El Vergel's chagras imply a constant reattunement of relations between people and their environments (Ingold 2012). Such relations have not been frozen in an ethnographic past, but rather have been influenced by an array of economic and political forces, as well as local desires and aspirations that shape what people do in their everyday lives and how their livelihoods are constituted. Moreover, TEK includes processes of creativity and innovation as individuals navigate the contemporary environments of their lives, drawing upon their histories and cultural memories linking the past with possible futures (Davidson-Hunt 2003).

According to our research and despite having changed their structure, function, and meaning, chagras continue to be part of Ticuna everyday life in El Vergel. The transformative capacity of TEK offers multiple possibilities that allow the chagra system to persist. The chagra remains not only a repository but also a ground for knowledge production, both of which are key for developing sustainable trajectories needed for the resilience of indigenous peoples and their land-use systems (Folke et al. 1998). Thus, as a land-use system and social-ecological unit, the chagra is an important vehicle for innovation and the creation of knowledge. It also offers an empirical lens to see how indigenous peoples' knowledge systems and ways of life evolve in changing 
contexts. Changes in the chagra and related TEK should be seen as expressions of knowledge creation and transformation instead of as a loss of ecological knowledge (Gómez-Baggethun et al. 2013).

\section{CONCLUSIONS}

Our case study contributes to policy design around sustainable pathways for indigenous territories in the Amazon region and brings in key elements of how local transformations allow sustainable land-uses in changing environments. Strategies to accelerate production cycles have been developed in El Vergel to balance the time demands of wage labor and other activities, without letting the chagra disappear. Innovation and learning have been key for chagras to remain active and as an important part of the local land-use system. Thus, policies for sustainability transformations in the Amazon forest must promote TEK's transformative capability, as well as create and maintain the adaptive capability of local communities (Holling 2001).

Governmental agencies, NGOs, environmental authorities, and other stakeholders must give TEK the chance to change, generate, and regenerate, as well as sustain innovation and the ability of local communities to adapt their knowledge to navigate change and to maintain their culture and livelihoods. Territorial planning and conservation initiatives for a more sustainable future of the Amazon, in which social-ecological relations between indigenous peoples and the rainforest are sustained, requires the development of opportunities and spaces for TEK to be conserved, transformed, and created. Such scenarios must retain valuable land-use systems, like the chagra, that support the Ticuna of El Vergel and other indigenous peoples' capacity to navigate change while sustaining themselves and retaining control over their territories.

Responses to this article can be read online at: http://www.ecologyandsociety.org/issues/responses. php/10416

\begin{abstract}
Acknowledgments:
We express our gratitude to the families of El Vergel who opened themselves so we could understand part of their complex and outstanding reality. Special acknowledgments to Katherine Turner for her generous collaboration. We thank the Pontificia Universidad Javeriana for financing the publication of this manuscript.
\end{abstract}

\section{LITERATURE CITED}

Adams, C., L. Chamlian Munari, N. Van Vliet, R. S. Sereni Murrieta, B. A. Piperata, C. Futemma, N. Novaes Pedroso, C. Santos Taqueda, M. Abrahão Crevelaro, and V. L. SpressolaPrado. 2013. Diversifying incomes and losing landscape complexity in Quilombola shifting cultivation Ccmmunities of the Atlantic Rainforest (Brazil). Human Ecology 41(1):119-137. http://dx.doi.org/10.1007/s10745-012-9529-9

Alexiades, M. N. 2009. The cultural and economic globalisation of traditional environmental knowledge systems. Pages 68-98. in S. Heckler, editor. Landscape, process and power: re-evaluating traditional environmental knowledge. Berghahn, London, UK.
Andoque, I., and H. Castro. 2012. La vida de la chagra: saberes tradicionales y prácticas locales para la adaptación al cambio climático en la comunidad El Guacamayo. Tropenbos International, Bogotá, Colombia. [online] URL: http://www. tropenbos.org/file.php/1345/chagraweb9.pdf

Andrade, Á. 1990. Sistemas agrícolas tradicionales en el medio río Caquetá. Pages 63-86 in F. Correa, editor. La selva humanizada. Ecología alternativa en el trópico húmedo colombiano. Fondo Editorial CEREC, Bogotá, Colombia.

Barthel, S., C. Folke, and J. Colding. 2010. Social-ecological memory in urban gardens: Retaining the capacity for management of ecosystem services. Global Environmental Change 20:255-265. http://dx.doi.org/10.1016/j.gloenvcha.2010.01.001

Bates, P., M. Chiba, S. Kube, and D. Nakashima. 2009. Learning and knowing in indigenous societies today. UNESCO, Paris, France. [online] URL: http://unesdoc.unesco.org/ images/0018/001807/180754e.pdf

Berkes, F. 2012. Sacred ecology. Third edition. Routledge, Abingdon, UK.

Berkes, F., J. Colding, and C. Folke. 2000. Rediscovery of traditional ecological knowledge as adaptive management. Ecological Applications 10(5):1251-1262. http://dx.doi. org/10.1890/1051-0761(2000)010[1251:ROTEKA]2.0.CO;2

Bríñez Pérez, A. H. 2002. Casabe: símbolo cohesionador de la cultura huitoto. Ministerio de Cultura, Bogotá, Colombia.

Bürgi, M., A. M. Hersperger, and N. Schneeberger. 2004. Driving forces of landscape change - current and new directions. Landscape Ecology 19(8):857-868. http://dx.doi.org/10.1007/ s10980-004-0245-8

Candelo, C., G. A. Ortiz, and B. Unger. 2003. Hacer talleres. Una guía práctica para capacitadores. WWF Colombia, Cali, Colombia. [online] URL: http://awsassets.panda.org/downloads/ hacer talleres guia para capacitadores wwf.pdf

Carrizosa, J. 2016. Deforestación, politicas nacionales y derechos de los pueblos indígenas en la Amazonía colombiana. AFRO Editores Impresores, Bogotá, Colombia. [online] URL: https:// reliefweb.int/sites/reliefweb.int/files/resources/Abril03 Deforestacion Completo FPP Lo-Res $\% 20 \% 281 \% 29$.pdf

Correa, F. 1990. Introducción. Pages 17-38 in F. Correa, editor. La selva humanizada: ecología alternativa en el trópico húmedo colombiano. Fondo Editorial CEREC, Bogotá, Colombia.

Coomes, O. T., F. Grimard, and G. J. Burt. 2000. Tropical forests and shifting cultivation: secondary forest fallow dynamics among traditional farmers of the Peruvian Amazon. Ecological Economics 32:109-124. http://dx.doi.org/10.1016/S0921-8009(99) 00066-X

Coomes, O. T., Y. Takasaki, and J. M. Rhemtulla. 2017. What fate for swidden agriculture under land constraint in tropical forests? Lessons from a long-term study in an Amazonian peasant community. Journal of Rural Studies 54:39-51. http://dx.doi. org/10.1016/j.jrurstud.2017.06.002

Cramb, R. A., C. J. Pierce Colfer, W. Dressler, P. Laungaramsri, Q. T. Le, E. Mulyoutami, N. L. Peluso, and R. L. Wadley. 2009. 
Swidden transformations and rural livelihoods in Southeast Asia. Human Ecology 37(3):323-346. http://dx.doi.org/10.1007/ $\underline{\text { s10745-009-9241-6 }}$

Davidson-Hunt, I. J. 2003. Indigenous lands management, cultural landscapes and Anishinaabe people of Shoal Lake, Northwestern Ontario, Canada. Environments 31:21-41.

Davidson-Hunt, I. J. 2006. Adaptive learning networks: developing resource management knowledge through social learning forums. Human Ecology 34(4):593-614. http://dx.doi. org/10.1007/s10745-006-9009-1

Davidson-Hunt, I. J., H. Asselin, F. Berkes, K. Brown, C. J. Idrobo, M. A. Jones, P. McConney, R. M. O'Flaherty, J. P. Robson, and M. Rodriguez. 2016. The use of biodiversity for responding to globalized change: a people in Nature approach to support the resilience of rural and remote communities. Pages 19-31 in I. J. Davidson-Hunt, H. Suich, S. S. Meijer, and N. Olsen, editors. People in Nature: valuing the diversity of interrelationships between people and nature. IUCN, Gland, Switzerland. [online] URL: https://portals.iucn.org/library/sites/library/files/ documents/2016-038.pdf

Ellen, R. 2007. Modern crises and traditional strategies: local ecological knowledge in island Southeast Asia. Berghahn, Oxford, UK.

Ellis, E. C. 2015. Ecology in an anthropogenic biosphere. Ecological Monographs 85(3):287-331. http://dx.doi. org/10.1890/14-2274.1

Foley, J. A., R. DeFries, G. P. Asner, C. Barford, G. Bonan, S. R. Carpenter, F. S. Chapin, M. T. Coe, G. C. Daily, H. K. Gibbs, J. H. Helkowski, T. Holloway, E. A. Howard, C. J. Kucharik, C. Monfreda, J. A. Patz, I. C. Prentice, N. Ramankutty, and P. K. Snyder. 2005. Global consequences of land use. Science (309):570-574. http://dx.doi.org/10.1126/science.1111772

Folke, C., F. Berkes, and J. Colding. 1998. Ecological practices and social mechanisms for building resilience and sustainability. Pages 414-436 in F. Berkes and C. Folke, editors. Linking social and ecological systems: management practices and social mechanisms for building resilience. Cambridge University Press, Cambridge, UK.

Fox, J., Y. Fujita, D. Ngidang, N. Peluso, L. Potter, N. Sakuntaladewi, J. Sturgeon, and D. Thomas. 2009. Policies, political-economy, and swidden in Southeast Asia. Human Ecology 37(3):305-322. http://dx.doi.org/10.1007/s10745-009-9240-7

Franco, R. 1992. Frontera indígena en la Amazonía Colombiana. Pages 328-353 in G. Andrade, A. Hurtado, and R. Torres, editors. Amazonia colombiana: diversidad y conflicto. Colciencias, Bogotá, Colombia.

Gallini, S., S. de la Rosa, and R. Abello. 2015. Historia ambiental. Pages 1-76 in P. Ungar and A. Osejo, editors. Hojas de ruta. Guías para el estudio socioecológico de la alta montaña en Colombia. Instituto de Investigación de Recursos Biológicos Alexander von Humboldt, Bogotá, Colombia.

Godoy, R., V. Reyes-García, E. Byron, W. R. Leonard, and V. Vadez. 2005. The effect of market economies on the well-being of indigenous peoples and on their use of renewable natural resources. Annual Review of Anthropology 34:121-138. http://dx. doi.org/10.1146/annurev.anthro.34.081804.120412

Gómez, A. J. 2015. Presentación. A propósito de los procesos de colonización en la selva oriental colombiana. Pages 15-23 in A. J. Gómez, editor. Pioneros. Colonos y pueblos. Memoria y testimonio de los procesos de colonización y urbanización de la Amazonia Colombiana. Universidad Nacional de Colombia, Bogotá, Colombia.

Gómez-Baggethun, E., E. Corbera, and V. Reyes-García. 2013. Traditional ecological knowledge and global environmental change: research findings and policy implications. Ecology and Society 18(4):72. http://dx.doi.org/10.5751/ES-06288-180472

Grogan, K., T. Birch-Thomsen, and J. Lyimo. 2013. Transition of shifting cultivation and its impact on people's livelihoods in the Miombo Woodlands of Northern Zambia and South-Western Tanzania. Human Ecology 41(1):77-92. http://dx.doi.org/10.1007/ s10745-012-9537-9

Heckler, S. 2009. Landscape, process and power: re-evaluating traditional environmental knowledge. Berghahn, London, UK.

Heinimann, A., C. Hett, K. Hurni, P. Messerli, M. Epprecht, L. Jørgensen, and T. Breu. 2013. Socio-economic perspectives on shifting cultivation landscapes in northern Laos. Human Ecology 41(1):51-62. http://dx.doi.org/10.1007/s10745-013-9564-1

Hersperger, A. M., M. Gennaio, P. H. Verburg, and M. Bürgi. 2010. Linking land change with driving forces and actor: four conceptual models. Ecology and Society 15(4):1. http://dx.doi. org/10.5751/ES-03562-150401

Holling, C. S. 2001. Understanding the complexity of economic, ecological and social systems. Ecosystems 4:390-405. http://dx. doi.org/10.1007/s10021-001-0101-5

Hugh-Jones, C. 1979. From the Milk River. Spatial and temporal processes in Northwest Amazonia. Cambridge University Press, Cambridge, UK.

Hurni, K., C. Hett, A. Heinimann, P. Messerli, and U. Wiesmann. 2013. Dynamics of shifting cultivation landscapes in northern Laos PDR between 2000 and 2009 based on an analysis of MODIS time series and landsat images. Human Ecology 41 (1):21-36. http://dx.doi.org/10.1007/s10745-012-9551-y

Idrobo, C. J., and I. J. Davidson-Hunt. 2012. Adaptive learning, technological innovation and livelihood diversification: the adoption of pound nets in Rio de Janeiro State, Brazil. Maritime Studies 11(1):3. http://dx.doi.org/10.1186/2212-9790-11-3

Ingold, T. 2000. The perception of the environment: essays on livelihood, dwelling and skill. Routledge, London, UK. http://dx. doi.org/10.4324/9780203466025

Ingold, T. 2012. Toward an ecology of materials. Annual Review of Anthropology 41:427-442. https://doi.org/10.1146/annurevanthro-081309-145920

Instituto Amazónico de Investigaciones Científicas (Sinchi). 2016. Departamento del Amazonas. Instituto Amazónico de Investigaciones Científicas, Bogotá, Colombia. [online] URL: http://siatac.co/Atlas/amazonas.html 
Junqueira, A. B., C. J. M. Almekinders, T.-J. Stomph, C. R. Clement, and P. C. Struik. 2016. The role of Amazonian anthropogenic soils in shifting cultivation: learning from farmers' rationales. Ecology and Society 21(1):12. http://dx.doi. org/10.5751/ES-08140-210112

Kawulich, B. B. 2005. Participant observation as a data collection method. Forum Qualitative Sozialforschung/Forum: Qualitative Social Research 6(2):1-19. [online] URL: http://www.qualitativeresearch.net/index.php/fqs/article/view/466/997

Kleinman, P. J. A., D. Pimentel, and R. B. Bryant. 1995. The ecological sustainability of slash-and-burn agriculture. Agriculture, Ecosystems and Environment 52(2-3):235-249. http:// dx.doi.org/10.1016/0167-8809(94)00531-I

Lambin, E. F, H. J. Geist, and E. Lepers. 2003. Dynamics of landuse and land-cover change in tropical regions. Annual Review of Environment and Resources 28:205-241. http://dx.doi.org/10.1146/ annurev.energy.28.050302.105459

Lambin, E. F., and P. Meyfroidt. 2010. Land use transitions: socio-ecological feedback versus socio-economic change. Land Use Policy 27(2):108-118. http://dx.doi.org/10.1016/j.

landusepol.2009.09.003

Lambin, E. F., B. L. Turner, H. J. Geist, S. B. Agbola, A. Angelsen, J. W. Bruce, O. T. Coomes, R. Dirzo, G. Fischer, C. Folke, P. S. George, K. Homewood, J. Imbernon, R. Leemans, X. Li, E. F. Moran, M. Mortimore, P. S. Ramakrishnan, J. F. Richards, H. Skanes, W. Steffen, G. D. Stone, U. Svedin, T. A. Veldkamp, C. Vogel, and J. Xu. 2001. The causes of land-use and land-cover change: moving beyond the myths. Global Environmental Change 11:261-269. http://dx.doi.org/10.1016/S0959-3780(01)00007-3

Laurance, W. F., J. L. C. Camargo, R. C. Luizao, S. G. Laurance, S. L. Pimm, E. M. Bruna, P. C. Stouffer, G. B. Williamson, J. Benítez-Malvido, H. L. Vasconcelos, K. S. Van Houtan, C. E. Zartman, S. A. Boyle, R. K. Didham, A. Andrade, and T. E. Lovejoy. 2011. The fate of Amazonian forest fragments: a 32-year investigation. Biological Conservation 144:56-67. http://dx.doi. org/10.1016/j.biocon.2010.09.021

Lave, J. 2009. The practice of learning. Pages 200-208 in K. Illeris, editor. Contemporary theories of learning: learning theorists ... in their own words. Routledge, New York, New York, USA.

Maffi, L. 2001. On the interdependence of biological and cultural diversity. Pages 1-50 in L. Maffi, editor. On biocultural diversity: linking language knowledge and the environment. Smithsonian Institution, Washington, D.C., USA.

Mendoza, D., O. Rodríguez., C. Mendoza, E. Mendoza, A. Gómez, L. Kutdo, J. Ortiz, and J. Crisóstomo. 2017. Moniya ringo mujer de abundancia y reproducción, estudio de caso de la chagra de la Gente de Centro Resguardo Indígena de Monochoa. Instituto Sinchi, Bogotá, Colombia.

Mertz, O. 2002. The relationship between length of fallow and crop yield in shifting cultivation: a rethinking. Agroforestry System 55(2):149-159.

Millennium Ecosystem Assessment (MEA). 2003. Ecosystems and human well-being. Pages 71-84 in Ecosystems and human well- being: a framework for assessment. Island, Washington, D.C., USA. [online] URL: http://pdf.wri.org/ecosystems_human_wellbeing. pdf

Morzillo, A. T., C. R. Colocousis, D. K. Munroe, K. P. Bell, S. Martinuzzi, D. B. Van Berkel, M. J. Lechowicz, B. Rayfield, and B. McGill. 2015. "Communities in the middle": interactions between drivers of change and place-based characteristics in rural forest-based communities. Journal of Rural Studies 42:79-90. http://dx.doi.org/10.1016/j.jrurstud.2015.09.007

Nabhan, G. P., K. Chambers, D. Tecklin, E. Perramond, and T. E. Sheridan. 2011. Ethnobiology for a diverse world - Defining new disciplinary trajectories: mixing political ecology with ethnobiology. Journal of Ethnobiology 31(1):1-3. http://dx.doi. org/10.2993/0278-0771-31.1.1

Oyuela, A., and J. J. Vieco. 1999. Mitades, clanes y casas del Trapecio Amazónico colombiano: una perspectiva numérica de los Ticuna. Amazonia em Cadernos 5:39-68. [online] URL: $\underline{\text { http:// }}$ users.clas.ufl.edu/caycedo/historical\%20ecology/Amazonas/1999\% 20Ticunas $\% 20$ manaus.pdf

Padoch, C., K. Coffey, O. Mertz, S. J. Leisz, J. Fox, and R. L. Wadley. 2007. The demise of swidden in Southeast Asia? Local realities and regional ambiguities. Geografisk Tidsskrift-Danish Journal of Geography 107(1):29-41. http://dx.doi. org//10.1080/00167223.2007.10801373

Padoch, C., and M. Pinedo-Vásquez. 2010. Saving slash-and-burn to save biodiversity. Biotropica 42(5):550-552. http://dx.doi. org/10.1111/j.1744-7429.2010.00681.X

Peña Venegas, C. P. 2015. People, soil and manioc interactions in the upper Amazon region. Dissertation. Wageningen University, Wageningen, Netherlands. [online] URL: http://edepot.wur. $\underline{\text { n1/347116 }}$

Perrault, T. 2005. Why chacras (swidden gardens) persist: agrobiodiversity, food security, and cultural identity in the Ecuadorian Amazon. Human Organization 64:327-239. http://dx. doi.org/10.17730/humo.64.4.e6tymmka388rmybt

Ramankutty, N., A. T. Evan, C. Monfreda, and J. A. Foley. 2008. Farming the planet: geographic distribution of global agricultural lands in the year 2000. Global Biogeochemical Cycles 22(1):1-19. http://dx.doi.org/10.1029/2007GB002952

Reyes-García, V., V. Vadez, E. Byron, L. Apaza, W. R. Leonard, E. Pérez, and D. Wilkie. 2005. Market economy and the loss of folk knowledge of plant uses: estimates from the Tsimane' of the Bolivian Amazon Current Anthropology 46(4):651-656. [online] URL: https://www.journals.uchicago.edu/doi/pdfplus/10.1086/432777

Rodríguez, A. 2013. Las plantas cultivadas por la gente de centro en la Amazonia colombiana. Tropenbos International, Bogotá, Colombia. [online] URL: http://www.tropenbos.org/file.php/1277/2plantas cultivadas gente centro.pdf

Rodríguez, C., and M. C. Van der Hammen. 1990. Ocupación y utilización del espacio por indígenas y colonos en el bajo Caquetá (Amazonia Colombiana). Pages 193-229 in F. Correa, editor. La selva humanizada: ecología alternativa en el trópico hummedo colombiano. Fondo Editorial CEREC, Bogotá, Colombia. 
Rodríguez, C., and M. C. Van der Hammen. 2014. Cuando el tiempo no hace caso: la memoria profunda de los eventos climáticos extremos y adaptación al cambio climático en comunidades indígenas de la Amazonia colombiana. Pages 81-100 in R. Lara and R. Vides-Almonacid, editors. Sabiduría y adaptación: el valor del conocimiento tradicional en la adaptación al cambio climático en América del Sur. IUCN, Quito, Ecuador. [online] URL: https://portals.iucn.org/library/sites/library/files/ documents/2014-001.pdf

Schmidt-Vogt, D., S. J. Leisz, O. Mertz, A. Heinimann, T. Thiha, P. Messerli, M. Epprecht, P. V. Cu, V. K. Chi, M. Hardiono, and T. M. Dao. 2009. An assessment of trends in the extent of swidden in Southeast Asia. Human Ecology 37(3):269-280. http://dx.doi. org/10.1007/s10745-009-9239-0

Schmook, B., N. van Vliet, C. Radel, M. de J. Manzón-Che, and S. McCandless. 2013. Persistence of swidden cultivation in the face of globalization: a case study from communities in Calakmul, Mexico. Human Ecology 41(1):93-107. http://dx.doi.org/10.1007/ $\underline{\text { s10745-012-9557-5 }}$

Triana-Moreno, L. A., N. C. Rodríguez, and J. García. 2006. Dinámica del sistema agroforestal de chagras como eje de la producción indígena en el Trapecio Amazónico (Colombia). Agronomía Colombiana. 24(1):158-169. [online] URL: http:// www.scielo.org.co/pdf/agc/v24n1/v24n1a18.pdf

Ullán de la Rosa, F. J. 2000. Los indios Ticuna del Alto Amazonas ante los procesos actuales de cambio cultural y globalización. Revista Española de Antropología Americana 291-336. [online] URL: http://www.humanas.unal.edu.co/colantropos/files/9714/7666/0546/ $\underline{\text { los indios Ticuna del Alto Amazonia.PDF }}$

Van der Hammen, M. C. 1992. Managing the world. Nature and society by the Yukuna of the Colombian Amazonia. Tropenbos Colombia, Bogotá, Colombia. [online] URL:

Van Vliet, N., O. Mertz, T. Birch-Thomsen, and B. Schmook. 2013. Is there a continuing rationale for swidden cultivation in the 21st century? Human Ecology 41(1):1-5. http://dx.doi. org/10.1007/s10745-013-9562-3

Van Vliet, N., O. Mertz, A. Heinimann, T. Langanke, U. Pascual, B. Schmook, C. Adams, D. Schmidt-Vogt, P. Messerli, S. Leisz, J.-C. Castella, L. Jørgensen, T. Birch-Thomsen, C. Hett, T. B. Bruun, A. Ickowitz, K. C. Vu, K. Yasuyuki, J. Fox, C. Padoch, W. Dressler, and A. D. Ziegler. 2012. Trends, drivers and impacts of changes in swidden cultivation in tropical forest-agriculture frontiers: a global assessment. Global Environmental Change 22 (2):418-429. http://dx.doi.org/10.1016/j.gloenvcha.2011.10.009

Vélez, G. A., and A. J. Vélez. 1999. Sistema agroforestal de las chagras indígenas el Medio Caquetá. Tropenbos International, Bogotá, Colombia.

von Hildebrand, P. 1975. Observaciones preliminares sobre utilización de tierras y fauna por los indígenas del río MiritiParana. Revista Colombiana de Antropología 18:190-258. [online] URL: http://biblioteca.icanh.gov.co/DOCS/MARC/texto/ REV-0915V18a-6.PDF
Walker, B., C. S. Holling, S. R. Carpenter, and A. Kinzig. 2004. Resilience, adaptability and transformability in social-ecological systems. Ecology and Society 9(2):5. http://dx.doi.org/10.5751/ ES-00650-090205

Westley, F., P. Olsson, C. Folke, T. Homer-Dixon, H. Vredenburg, D. Loorbach, J. Thompson, M. Nilsson, E. Lambin, J. Sendzimir, B. Banerjee, V. Galaz, S. van der Leeuw. 2011. Tipping toward sustainability: emerging pathways of transformation. $A M B I O$ 40:762-780. http://dx.doi.org/10.1007/s13280-011-0186-9 
Appendix 1. Uses and destination of species and landraces found in the chagras.

\begin{tabular}{|c|c|c|c|c|c|c|c|c|c|c|c|c|}
\hline \multirow[t]{2}{*}{ Chagra } & \multirow[t]{2}{*}{ Order } & \multirow[t]{2}{*}{ Family } & \multirow[t]{2}{*}{ Genus } & \multirow[t]{2}{*}{ Scientific name } & \multirow{2}{*}{$\begin{array}{l}\text { Landraces common } \\
\text { names }\end{array}$} & \multicolumn{4}{|l|}{ Uses ${ }^{\dagger}$} & \multicolumn{3}{|c|}{ Destination $\neq$} \\
\hline & & & & & & $\mathrm{F} \quad \mathrm{M}$ & $\mathrm{N}$ & $\mathrm{T}$ & $\mathrm{F}$ & $\mathrm{SC}$ & $\mathrm{S}$ & $\mathrm{N}$ \\
\hline \multicolumn{13}{|c|}{ Chagra 1} \\
\hline & Poales & BROMELIACEAE & Ananas & Ananas comosus & Yellow peel pineapple & $\mathrm{x}$ & & & & $\mathrm{x}$ & & \\
\hline & Poales & BROMELIACEAE & Ananas & Ananas comosus & Red peel pineapple & $\mathrm{x}$ & & & & $\mathrm{x}$ & $\mathrm{x}$ & \\
\hline & Poales & BROMELIACEAE & Ananas & Ananas comosus & Green peel pineapple & $\mathrm{x}$ & & & & $\mathrm{x}$ & $\mathrm{x}$ & \\
\hline & Arecales & ARECACEAE & Euterpe & Euterpe precatoria & Asaí & $\mathrm{x}$ & & & & $\mathrm{x}$ & & \\
\hline & Solanales & CONVOLVULACEAE & Ipomoea & Ipomoea batatas & Camote & $\mathrm{x}$ & & & & $\mathrm{x}$ & & \\
\hline & Malpighiales & EUPHORBIACEAE & Manihot & Manihot esculenta & Flor manioc (sweet) & $\mathrm{x}$ & & & & $\mathrm{x}$ & $\mathrm{x}$ & \\
\hline & Malpighiales & EUPHORBIACEAE & Manihot & Manihot esculenta & Lupuna manioc (bitter) & $\mathrm{x}$ & & & & $\mathrm{x}$ & $\mathrm{x}$ & \\
\hline & Malpighiales & EUPHORBIACEAE & Manihot & Manihot esculenta & Mandioca manioc (bitter) & $\mathrm{x}$ & & & & $\mathrm{x}$ & $\mathrm{x}$ & \\
\hline & Malpighiales & EUPHORBIACEAE & Manihot & Manihot esculenta & $\begin{array}{l}\text { Tresmesina manioc } \\
\text { (bitter) }\end{array}$ & $\mathrm{x}$ & & & & $\mathrm{x}$ & $\mathrm{x}$ & \\
\hline & Malpighiales & EUPHORBIACEAE & Manihot & Manihot esculenta & Vega manioc (sweet) & $\mathrm{x}$ & & & & $\mathrm{x}$ & $\mathrm{x}$ & \\
\hline & Zingiberales & MUSACEAE & Musa & Musa paradisiaca & Banana & $\mathrm{x}$ & & & & $\mathrm{x}$ & $\mathrm{x}$ & \\
\hline & Zingiberales & MUSACEAE & Musa & Musa sp & Bellaco plantain & $\mathrm{x}$ & & & & $\mathrm{x}$ & $\mathrm{x}$ & \\
\hline & Zingiberales & MUSACEAE & Musa & Musa sp & Manzana plantain & $\mathrm{x}$ & & & & $\mathrm{x}$ & $\mathrm{x}$ & \\
\hline & Zingiberales & MUSACEAE & Musa & Musa sp & Píldoro/guineo plantain & $\mathrm{x}$ & & & & $\mathrm{x}$ & $\mathrm{x}$ & \\
\hline & Zingiberales & MUSACEAE & Musa & Musa sp & Propio/común plantain & $\mathrm{x}$ & & & & $\mathrm{x}$ & $\mathrm{x}$ & \\
\hline & Laurales & LAURACEAE & Persea & Persea americana & Avocado & $\mathrm{x}$ & & & & $\mathrm{x}$ & & \\
\hline & Poales & POACEAE & Saccharum & $\begin{array}{l}\text { Saccharum } \\
\text { officinarum }\end{array}$ & Sugar cane & $\mathrm{x}$ & & & & $\mathrm{x}$ & $\mathrm{x}$ & \\
\hline & Malvales & MALVACEAE & Theobroma & Theobroma bicolor & Macambo & $\mathrm{x}$ & & & & $\mathrm{x}$ & & \\
\hline \multicolumn{13}{|c|}{ Chagra 2} \\
\hline & Ericales & LECYTHIDACEAE & Gustavia & $\begin{array}{l}\text { Calathea aff. } \\
\text { standleyi }\end{array}$ & Lijao & $\mathrm{x}$ & & & & $\mathrm{x}$ & & \\
\hline & Brassicales & CARICACEAE & Carica & Carica papaya & Papaya & $\mathrm{x}$ & & & & $\mathrm{x}$ & $\mathrm{x}$ & \\
\hline & Arecales & ARECACEAE & Elaeis & Elaeis guineensis & African palm & & $\mathrm{x}$ & & & & & $\mathrm{x}$ \\
\hline & Mirtales & MIRTACEAE & Eugenia & Eugenia stipitata & Arazá & $\mathrm{x}$ & & & & $\mathrm{x}$ & $\mathrm{x}$ & \\
\hline & Arecales & ARECACEAE & Euterpe & Euterpe precatoria & Asaí & $\mathrm{x}$ & & & & $\mathrm{x}$ & & \\
\hline & Fabales & MIMOSACEAE & Inga & Inga $s p$ & Chimbillo & $\mathrm{x}$ & & & & $\mathrm{x}$ & & \\
\hline & Fabales & MIMOSACEAE & Leucaena & $\begin{array}{l}\text { Leucaena } \\
\text { leucocephala }\end{array}$ & Leucaena & & $\mathrm{x}$ & & & & & $\mathrm{x}$ \\
\hline & Malpighiales & EUPHORBIACEAE & Manihot & Manihot esculenta & Lanza manioc (sweet) & $\mathrm{x}$ & & & & $\mathrm{x}$ & $\mathrm{x}$ & \\
\hline & Malpighiales & EUPHORBIACEAE & Manihot & Manihot esculenta & Pagúa manioc (sweet) & $\mathrm{x}$ & & & & $\mathrm{x}$ & $\mathrm{x}$ & \\
\hline
\end{tabular}


Malpighiales

Arecales

Zingiberales

Zingiberales

Zingiberales

Solanales

Poales

$\begin{array}{ll}\text { EUPHORBIACEAE } & \text { Manihot } \\ \text { ARECACEAE } & \text { Mauritia } \\ \text { MUSACEAE } & \text { Musa } \\ \text { MUSACEAE } & \text { Musa } \\ \text { MUSACEAE } & \text { Musa } \\ \text { SOLANACEAE } & \text { Solanum }\end{array}$

POACEAE

Poales

Poales

Arecales

Rosales

Fabales

Arecales

Malpighiales

Malpighiales

Malpighiales

Zingiberales

Zingiberales

Zingiberales

Zingiberales

Zingiberales

Zingiberales

Zingiberales

Laurales

Poales

Solanales
Ananas

Ananas

BROMELIACEAE

ARECACEAE

MORACEAE

MIMOSACEAE

ARECACEAE

EUPHORBIACEAE

EUPHORBIACEAE

EUPHORBIACEAE

MUSACEAE

MUSACEAE

MUSACEAE

MUSACEAE

MUSACEAE

MUSACEAE

MUSACEAE

LAURACEAE

POACEAE

SOLANACEAE

BROMELIACEAE

BROMELIACEAE

\section{Euterpe}

Manihot

Manihot

Manihot

Musa

Musa

Musa

Musa

Musa

Musa

Musa

Persea

Solanum

Ananas

Ananas
Manihot esculenta

Mauritia flexuosa

Musa sp

Musa sp

Musa sp

Solanum

sessiliflorum

Zea mays

Astrocaryum

\section{Brosimum}

Cedrelinga

Saccharum
Ananas comosus

Ananas comosus

Astrocaryum

chambira

Brosimum utile

Cedrelinga

catenaeformis

Euterpe precatoria

Manihot esculenta

Manihot esculenta

Manihot esculenta

Musa paradisiaca

Musa sp

Musa sp

Musa sp

Musa sp

Musa sp

Persea americana

Saccharum

officinarum

Solanum

sessiliflorum

Ananas comosus

Ananas comosus
Musa sp
Pan manioc (sweet)

Canangucho

Jartón plantain

Píldoro/guineo plantain

Propio/común plantain

Lulo

Maize

Red peel pineapple

No spine pineapple

Chambira

Lechoso

Achapo

Asaí

Lupuna manioc (bitter)

Pan manioc (sweet)

Vega manioc (sweet)

Banana

Bellaco plantain

Propio/común plantain

Sapo plantain

Píldoro/guineo plantain

Seda plantain

Engañaladrón plantain

Avocado

Sugar cane

Lulo $x$

X

$\mathrm{X}$

$\mathrm{X}$ 


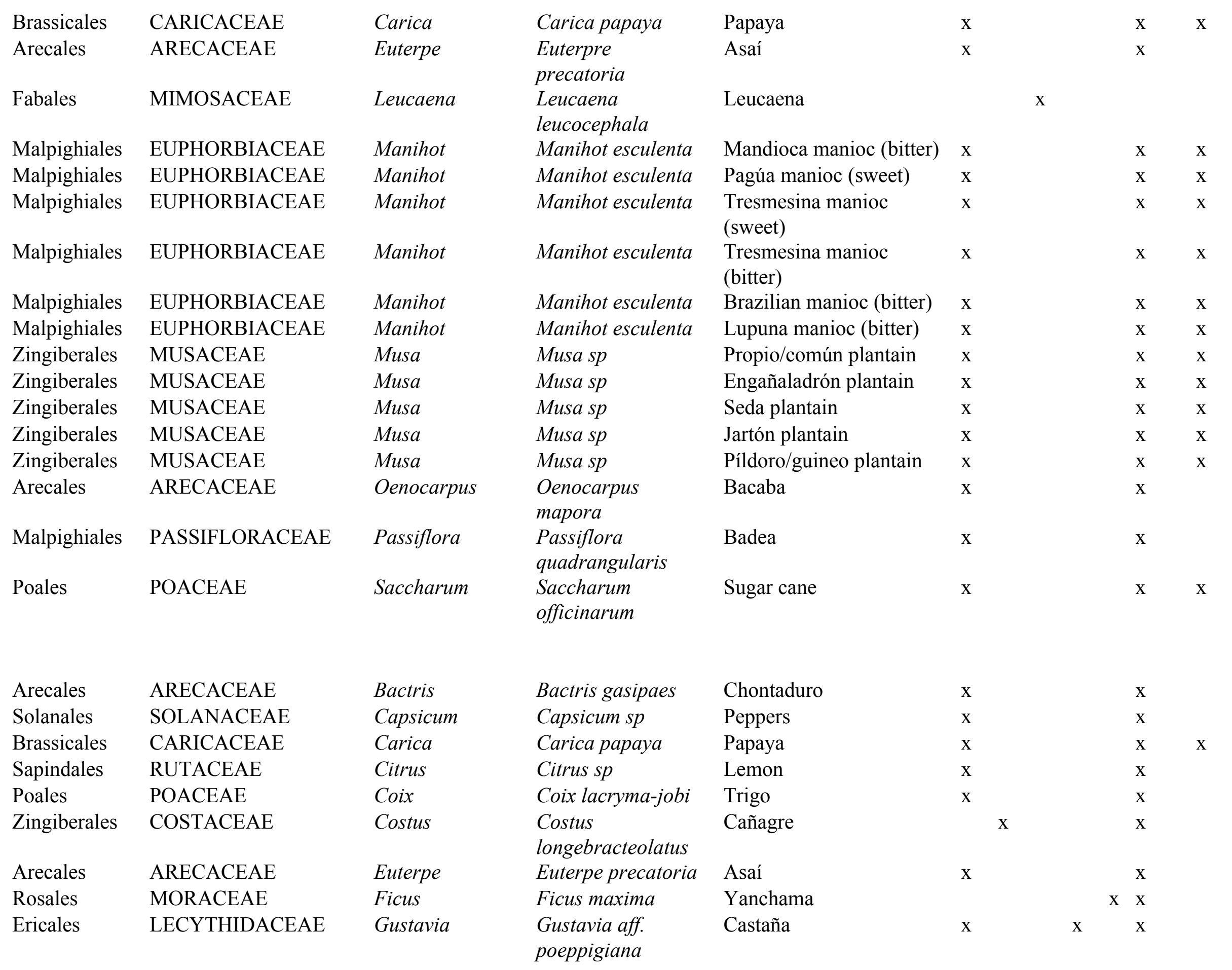




\begin{tabular}{|c|c|c|c|c|c|c|c|c|c|}
\hline Fabales & MIMOSACEAE & Inga & Inga edulis & Guamo & $\mathrm{x}$ & & & & $x$ \\
\hline Malpighiales & EUPHORBIACEAE & Manihot & Manihot esculenta & Pagúa manioc (sweet) & $\mathrm{x}$ & & & & $x$ \\
\hline Malpighiales & EUPHORBIACEAE & Manihot & Manihot esculenta & $\begin{array}{l}\text { Tresmesina manioc } \\
\text { (sweet) }\end{array}$ & $\mathrm{x}$ & & & & $x$ \\
\hline Malpighiales & EUPHORBIACEAE & Manihot & Manihot esculenta & Pan manioc (sweet) & $\mathrm{x}$ & & & & $x$ \\
\hline Zingiberales & MUSACEAE & Musa & Musa sp & Píldoro/guineo plantain & $\mathrm{x}$ & & & & $x$ \\
\hline Zingiberales & MUSACEAE & Musa & Musa sp & Bellaco plantain & $\mathrm{x}$ & & & & $x$ \\
\hline Malvales & MALVACEAE & Ochroma & $\begin{array}{l}\text { Ochroma } \\
\text { pyramidale }\end{array}$ & Topa & & & $\mathrm{x}$ & $\mathrm{x}$ & $x$ \\
\hline Rosales & CECROPIACEAE & Pourouma & $\begin{array}{l}\text { Pourouma } \\
\text { melinonii }\end{array}$ & Uvilla & $\mathrm{x}$ & & & & $x$ \\
\hline Ericales & SAPOTACEAE & Pouteria & Pouteria caimito & Caimo & $\mathrm{x}$ & $\mathrm{x}$ & & & $x$ \\
\hline Mirtales & MIRTACEAE & Psidium & Psidium guajava & Guayaba & $\mathrm{x}$ & & & & $x$ \\
\hline Poales & POACEAE & Saccharum & $\begin{array}{l}\text { Saccharum } \\
\text { officinarum }\end{array}$ & Sugar cane & $\mathrm{x}$ & & & & $x$ \\
\hline Solanales & SOLANACEAE & Solanum & $\begin{array}{l}\text { Solanum } \\
\text { sessiliflorum }\end{array}$ & Lulo & $\mathrm{x}$ & & & & $x$ \\
\hline Malvales & MALVACEAE & Theobroma & $\begin{array}{l}\text { Theobroma } \\
\text { grandiflorum }\end{array}$ & Copoazú & $\mathrm{x}$ & & & & $x$ \\
\hline Poales & BROMELIACEAE & Ananas & Ananas comosus & Yellow peel pineapple & $\mathrm{x}$ & & & & $x$ \\
\hline Solanales & SOLANACEAE & Capsicum & Capsicum $s p$ & Peppers & $\mathrm{x}$ & & & & $x$ \\
\hline Sapindales & MELIACEAE & Cedrela & Cedrela odorata & Cedro & & & $\mathrm{x}$ & & $x$ \\
\hline Arecales & ARECACEAE & Euterpe & Euterpe precatoria & Asaí & $\mathrm{x}$ & & & & $x$ \\
\hline Solanales & CONVOLVULACEAE & Ipomoea & Ipomoea batatas & Camote & $\mathrm{x}$ & & & & $x$ \\
\hline Malpighiales & EUPHORBIACEAE & Manihot & Manihot esculenta & Morrocoy manioc (bitter) & $\mathrm{x}$ & & & & $x$ \\
\hline Malpighiales & EUPHORBIACEAE & Manihot & Manihot esculenta & Pan manioc (sweet) & $\mathrm{x}$ & & & & $x$ \\
\hline- & - & Morphotype 1 & Morphotype 1 & Worm stick & $\mathrm{x}$ & & & & $x$ \\
\hline Zingiberales & MUSACEAE & Musa & Musa sp & Propio/común plantain & $\mathrm{x}$ & & & & $x$ \\
\hline Zingiberales & MUSACEAE & Musa & Musa sp & Bellaco plantain & $\mathrm{x}$ & & & & $x$ \\
\hline Zingiberales & MUSACEAE & Musa & Musa sp & Manzana plantain & $\mathrm{x}$ & & & & $x$ \\
\hline Poales & POACEAE & Saccharum & $\begin{array}{l}\text { Saccharum } \\
\text { officinarum }\end{array}$ & Sugar cane & $\mathrm{x}$ & & & & $x$ \\
\hline Malvales & MALVACEAE & Theobroma & $\begin{array}{l}\text { Theobroma } \\
\text { grandiflorum }\end{array}$ & Copoazú & $\mathrm{x}$ & & & & $\mathrm{x}$ \\
\hline
\end{tabular}


₹ SC: Self Consumption, S: Sale, N: None 